Ткаченко А. Л., к.т.н., с.н.с.;

Михайлов О. В.;

Педь М. О.;

Троцько Л. Г.;

Цимбал I. В.

Військовий інститут телекомунікацій та інформатизації, Київ

\title{
Оцінка термінів впровадження телекомунікаційних стандартів НАТО в Збройних Силах України
}

Резюме. В статті здійснена оцінка термінів введення телекомунікаційних стандартів НАТО в Збройних Силах України. Оцінка здійснена з використанням експертно-аналітичної процедури методу аналізу мереж. В якості прогнозованих термінів створення системи зв'язку і телекомунікації за стандартами НАТО пропонується три альтернативи - короткотермінова, середньотермінова та довготермінова.

Ключові слова: стандарти НАТО,телекомунікації, метод аналізу мереж, Збройні Сили України.

Постановка проблеми. Забезпечення якісними системами телекомунікації підрозділів Збройних Сил України сьогодні є одним із найважливіших завдань, які стоять в контексті їх системного реформування. Одним із ключових питань, яке необхідно вирішувати в сучасних умовах - яким чином $i$ коли здійснювати перехід на стандарти НАТО, не втрачаючи при цьому необхідного рівня функціонування систем зв'язку та передачі даних. Такий перехід необхідно здійснювати, враховуючи наявні можливості та ресурси які виділяються для реформування Сектору безпеки i оборони України. Запровадження в Збройних Силах України натовських систем зв'язку не $є$ простою заміною технічних засобів, які б відповідали стандартам НАТО або переведенням на нові нормативи використання. Запровадження стандартів НАТО це складне комплексне завдання, що вимагає поєднання, організаційних зусиль, технічних напрацювань, певної зміни способів управління та взаємодії. В цьому контексті актуалізується питання стосовно термінів переведення систем телекомунікації Збройних Сил України на стандарти НАТО. Дослідження цього питання i отримання відповіді на нього дасть змогу забезпечити планування заходів 3 переходу на стандарти НАТО без втрати ефективності вже існуючих систем телекомунікації.

Аналіз останніх досліджень i публікацій. Питання введення стандартів НАТО в України сьогодні досить грунтовно не вивчене. Особливо це стосується предметної області. Більша частина робіт присвячена вивченню концептуальних питань введення стандартів НАТО. В окремих роботах здійснено розкриття змісту процесу реформування та переведення Збройних Сил України на стандарти НАТО [1], ролі Міністерства оборони України в процесі імплементації стандартів НАТО в Україні [2] та ряд інших питань. Однак, більшість публікацій сьогодні носять переважно оглядовий характер, спрямований на інформування населення про процес впровадження та висвітлення загальної проблематики [3]. Конкретне питання впровадження телекомунікаційних стандартів НАТО та термінів досяжності сумісності в цій сфері $з$ державами-членами альянсу розглянуто не було.

Метою статті $\epsilon$ визначення прогнозних термінів впровадження телекомунікаційних стандартів НАТО в Збройних Силах України. Таке прогнозування дасть можливість для виконання завдань планування заходів оборони за напрямком реформування існуючої системи зв'язку та телекомунікації.

Виклад основного матеріалу. Для уникнення подвійного тлумачення в статті буде використовуватися термін “впровадження телекомунікаційних стандартів НАТО в Збройних Силах України " в наступному тлумаченні.

Впровадження телекомунікаџійних стандартів НАТО в Збройних Силах Украӥни процес, що передбачає введення спільного порядку дій, закріплення єдиної термінології і встановлення умов уніфікації технічних процесів в системах телекомунікації і зв'язку Збройних Сил України та країн НАТО, а також країн-партнерів. 
При цьому стандарти НАТО в сфері телекомунікації за аналогією [2] умовно можна розділити на адміністративні, оперативні та матеріально-технічні:

адміністративні стандарти визначають процеси управління та обміну інформацією, порядок роботи з документацією;

оперативні стандарти спрямовані на оперативне планування застосування систем телекомунікації та зв’язку;

матеріально-технічні

стандарти

визначають єдині вимоги до озброєння i військової техніки союзників, управлінню життєвим циклом, а також кодифікації предметів забезпечення в сфері телекомунікації.

Із зазначеного визначення випливає, що впровадження стандартів НАТО 3 телекомунікації є складним завданням, яке не зводиться лише до перекладу певних стандартів, таких як STANAG 4628 щодо протоколів зв'язку для військового застосування або STANAG 3910 щодо збільшення передачі даних, високошвидкісних каналів. Це завдання передбачає ряд організаційно-технічних заходів 3 технічного переоснащення, удосконалення рівня підготовки особового складу, зміну системи навчання, вирішення питань фінансування, поглиблену міжнародну взаємодію тощо. Крім цього, дотримання стандартів НАТО не передбачає переоснащення всіх телекомунікаційних систем зразками певної країни-члена НАТО. Тобто виникає питання вибору для технічного оснащення частин, підрозділів та установ.

Враховуючи складність питання, термін введення телекомунікаційних стандартів НАТО може бути оцінений 3 використанням методу аналітичних мереж [4], який дозволяє окреслити проблему 3 системних позицій та здійснити оцінювання спираючись на експертно-аналітичні міркування, що в умовах обмеженості кількісних даних дозволяє отримати правдоподібний результат.

Для використання такого методу необхідно створити групи (кластери) факторів, що впливають на проблему та альтернативи іiі вирішення. Ці групи необхідно поєднати різнотипними (односторонніми, багатосторонніми, зовнішніми та внутрішніми) зв'язками які відображають взаємодію всередині системи. Приклад такої мережі показаний на рис. 1.

В якості альтернатив для оцінки термінів доцільно обрати наступні:

впровадження стандартів НАТО протягом короткого терміну - два роки;

впровадження стандартів НАТО в середньостроковій перспективі 5-6 років;

впровадження стандартів НАТО в більш тривалий термін 7-9 років.

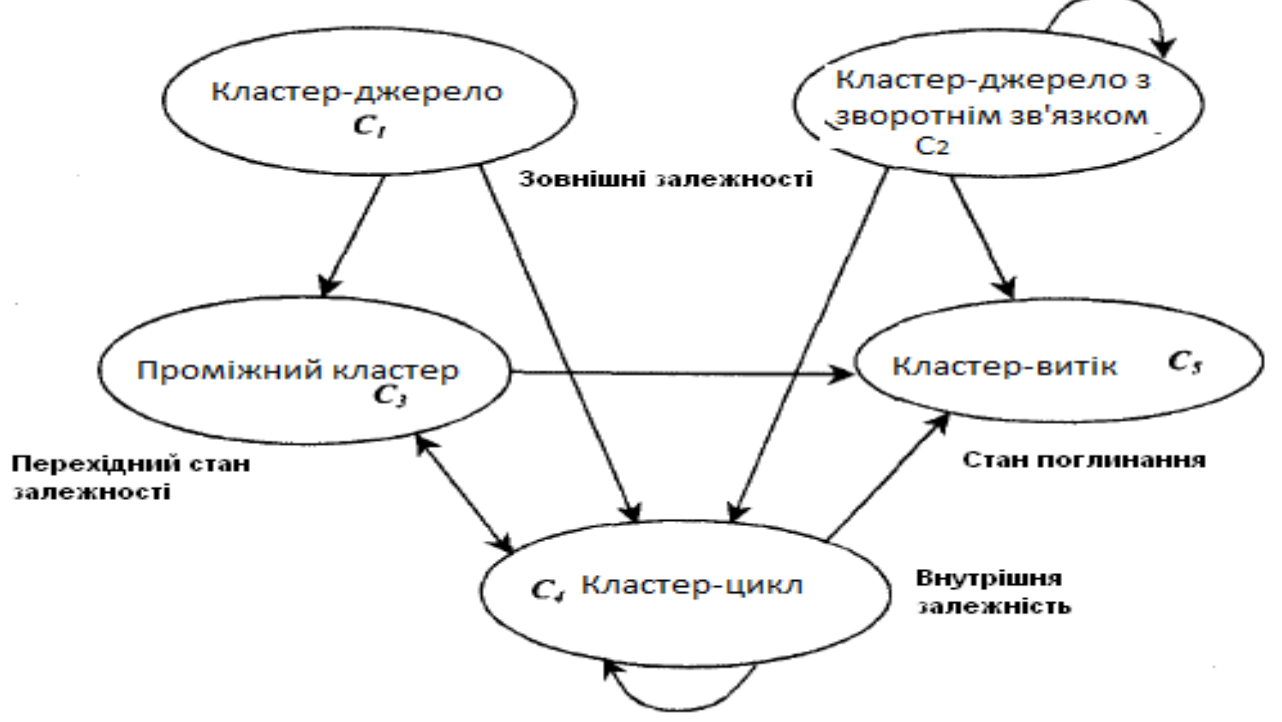

Рис. 1. Приклад мережі для вирішення задачі оцінювання

До кластерів, відповідно до наведеного вище визначення доцільно віднести наступні.

1. Впровадження адміністративних стандартів в телекомунікаціях ЗС України. Вони включають:

переклад i адаптацію керівних документів, що регулюють телекомунікаційну діяльність в рамках НАТО - 1a; створення або реформування адміністративних підрозділів, адаптованих під стандарти НАТО - 2a;

впровадження процедур за стандартами НАТО в телекомунікаціях ЗС України - 3а.

2. Впровадження стандартів спрямованих на оперативне планування застосування систем телекомунікації та зв'язку. Вони включають: 
перехід від існуючих стандартів і процедур до прийнятих в НАТО - 1b;

підготовка кадрів, що можуть працювати за стандартами НАТО в телекомунікаціях на практиці - $2 \mathrm{~b}$;

переведення частин і підрозділів зв' язку i телекомунікацій на стандарти НАТО - 3 b.

3. Впровадження матеріально-технічних стандартів. Вони включають:

переведення телекомунікаційної техніки на стандарти НАТО - 1c;

розробка і створення окремих система телекомунікації на основі стандартів НАТО 2c.
4. Фінансування процесу впровадження телекомунікаційних стандартів НАТО в Збройних Силах України. Вони включають:

фінансові умови для впровадження стандартів НАТО в сфері телекомунікацій в ЗС України- 1d;

необхідний обсяг фінансування для впровадження стандартів НАТО в телекомунікаціях 3С України- 2d.

Мережа для оцінювання термінів для впровадження телекомунікаційних стандартів НАТО в Збройних Силах України показана на рис. 2.

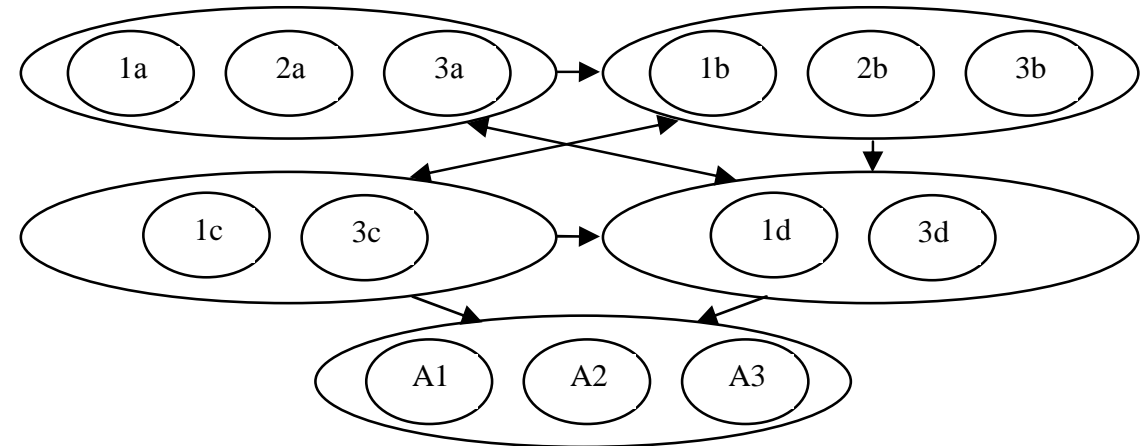

Рис. 2. - Мережа для оцінювання термінів для впровадження телекомунікаційних стандартів НАТО в Збройних Силах України

Оцінювання кластерів мережі рис. 2 здійснювалося 3 використанням стандартної шкали [4] та обчислювальних можливостей MS Excel. Результат 3 оцінювання термінів показаний на рис. 3. Відповідно до цього результату більш реальною для сьогоднішніх умов є термін 7-9 років. Це пояснюється рядом причин, серед яких головними $\epsilon$ значний обсяг фінансових ресурсів, необхідний для вирішення технічних питань (оснащення і переобладнання), неготовність до переходу рядового та керівного складу (необхідність засвоєння нових термінів i стандартів в практичній діяльності потребує тривалого періоду). Фактично робота 3 впровадження стандартів НАТО в ЗС України почалася в 2015 році, а імплементація стандартів відбулася лише в 2016 [5]. В умовах, коли питання фінансового забезпечення впровадження стандартів не вирішене остаточно говорити про стислі терміни не має сенсу.

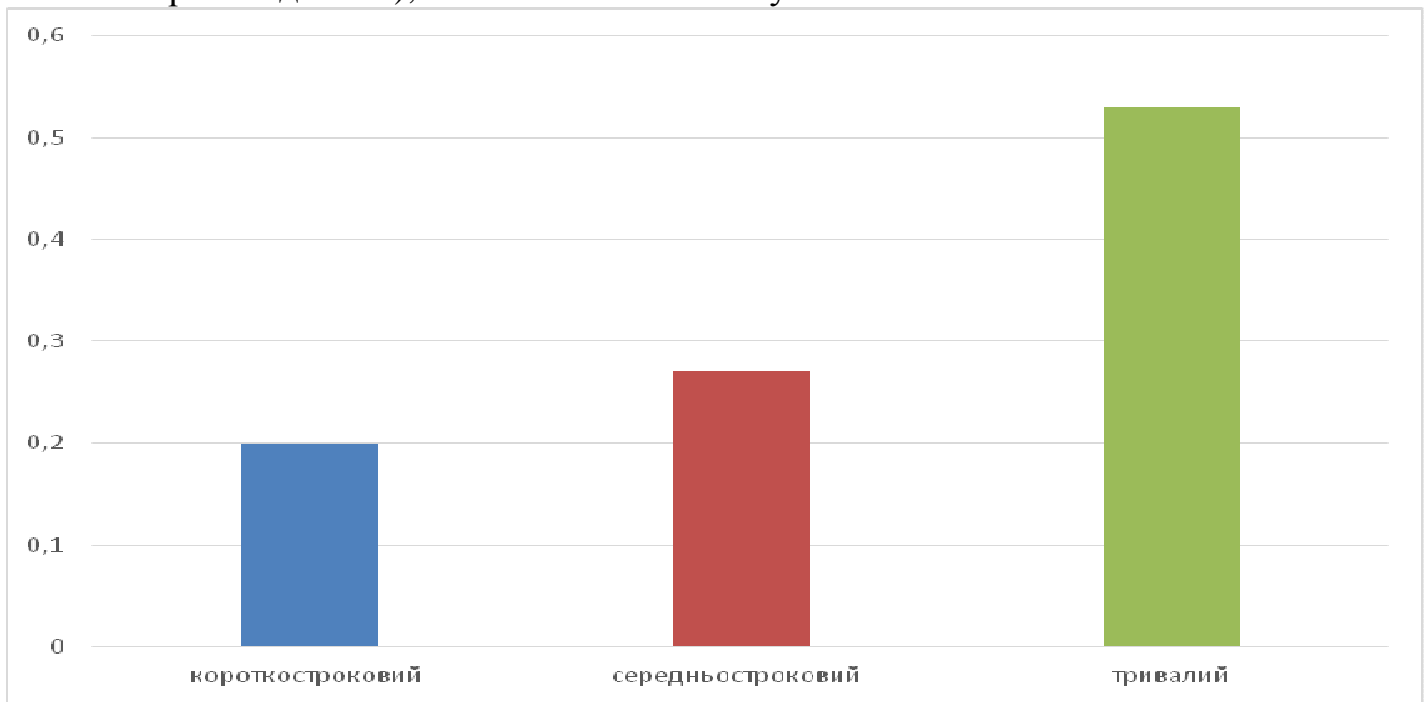

Рис. 3. - Результат оцінювання термінів для впровадження телекомунікаційних стандартів НАТО в Збройних Силах України 
